\title{
Az Egri Egyházmegye papságának liturgikus könyve (1768)*
}

\section{Bevezetés}

Az egri Főegyházmegyei Könyvtár gyüjteményének különleges darabja az a szertartáskönyv, amelynek teljes címe így hangzik: Rituale Agriense, seu formula agendorum, in administratione Sacramentorum, ac caeteris ecclesiae publicis functionibus. Jussu et authoritate excellentissimi, illustrissimi ac reverendissimi domini, domini Caroli e comitibus Eszterhazy de Galantha, perpetui in Frakno arcium et dominiorum Pápa, Ugod et Devecser haereditarii domini, Dei et Apostolicae Sedis gratia episcopi Agriensis, incl[ytorum] comitatuum Hevess et Exterioris Szólnok articulariter unitorum supremi, et perpetui comitis, utriusque S[acrati]S[simae] Caes[areae] et Apost[olicae] regiae majest[atis] status consil[iarii] actual[is] intimi, etc. etc. Agriae, typis scholae episcopalis. Anno M.DCC.LXVIII. ${ }^{1}$

A mű tartalmát tekintve öt fejezetre oszlik:

1. rész: szentségek (keresztség, bérmálás, bűnbánat, oltáriszentség, betegek kenete, házasság), kivéve az egyházi rend;

2. rész: beteglátogatás, elhalálozás előtti áldások, temetés;

3. rész: rendes és rendkívüli áldások;

4. rész: körmenetek, litániák;

5. rész: ördögűzés.

* Tanulmányunk az Acta Academiae Pedagogicae Agriensis. Sectio Historiae. Nova Series. Tom. XXXV. Red.: János Makai. Eger 2008. 87-96. periodikában megjelent írásunk módosított változata.

1 A latin nyelvű szöveg magyar fordítása: „A szentségek kiszolgáltatásához és az egyház többi közfeladatának elvégzéséhez használatos egri rituále, azaz szertartáskönyv. A kegyelmes, méltóságos és főtisztelendő úrnak, galántai Eszterházy Károly grófnak, Fraknó vára örökös urának, Pápa, Ugod és Devecser uradalmak örökletes urának, Isten és az Apostoli Szék kegyelméből egri megyéspüspöknek, tekintetes Heves és Külső-Szolnok vármegyék törvénycikkekkel szabályozott unitusai (görögkatolikusai) örökös és főispánjának, a szentséges császári és apostoli királyi felség valóságos belső titkos tanácsosának stb. stb. parancsára és végzéséből. [Szedetett] Egerben, a püspöki iskola betűivel, az 1768. esztendőben.” Az egri rituále könyvtári jelzete: HK 0073. A legfrissebben közreadott nyomdatörténeti munkában (egyéb lelőhelyadatokkal is kiegészítve) lásd: Mizera Tamás - Nagy Andor - Verók Attila: A könyvkiadó egri Líceum. Történet és kiadványjegyzék I. (1755-1852). (Kulturális Örökség 7.) Budapest-Eger 2017. 136-137. Nr. 257. 
Az Egri Egyházmegye papjai számára készült szerkönyv 1768-ban a vármegyeházán működő püspöki nyomdából került ki. A szedési munkálatokat Purhardt György nyomdász végezte, a nyomtatáshoz szükséges papír beszerzése a Pozsony megyei pilavöröskői papírmalomból történt. Az áru Pozsonyból Pest érintésével a püspökség szekerein érkezett Egerbe. A nyomda 1761 óta meglehetősen komoly felszereléssel dolgozott: három nyomtatópréssel és számos betűkészlettel, amelynek jelentős részét 1768 májusában felújították, így korszerüsítve az amúgy is tekintélyes berendezést. ${ }^{2}$

A páratlanul értékes munka bevezetőjében - magyar fordításban - az alábbi sorok olvashatók: "Csodálatra méltó tetteinek emlékezetes dolgai közepette, amelyeket az Úr, a mi Megváltónk az emberiség üdvére az Ö végtelen bölcsessége folytán létrehozott, és a földön küzdö egyházának - amelyet vérével szerzett - mint irántunk való szeretete és el nem múló öröksége megtartásának igen hathatós és készséges, valamint állandó jelét apostolainak szolgálatára és igehirdetésére jóakaratúan rábizta, s méltónak tartotta elismerni; és nem utolsósorban az igen tiszteletre méltó szentségeket, úgy mint Krisztus vérének és érdemeinek teljes edényét, amelyeket, ha méltóképpen használunk, ha megfelelö módon és idöben alkalmazunk, akkor nemcsak megtisztultan és a bünöktöl feloldozva születünk üjjá Isten fiainak reménységére, hanem annyival növekszünk és erösödünk is az égi erényben, ahányszor annak részeseivé válunk.

Ezért van az, hogy a katolikus anyaszentegyház kezdettöl fogva hivei lelki üdvéert és az erények gyarapodásáért buzgólkodik, és semmi sem kivánatosabb a számára, mint az, hogy a szentségeket minden idöben pontosan és illö módon kiszolgáltassák azok, akik a lelkek gondviselését ünnepélyes és szent szertartásokkal szolgálják, s amelyeket a titkok méltósága és szentsége végett a katolikus egyház már régen létrehozott; és azokat nagy áhitattal, hittel, reménnyel és szeretettel támogassák ugyanazok, akik számára az üdvösség nagy becsben van, vagy pedig akik ezen [szertartások] nélkül nem tudnak sem megigazulni, sem az egyszer megszerzett [szentségekben] kitartóan megmaradni vagy növekedni."'3

Az idézett szövegben Eszterházy Károly egri megyéspüspök (1762-1799) két okot jelölt meg, miért tartotta fontosnak a kiadvány megjelentetését. Először is azért, hogy egyházmegyéje plébánosai számára olyan kézikönyv álljon rendelkezésre, amely a szentmisén kívüli papi teendők ellátásához nyújt hasznos útmutatást. Másodszor, hogy a lelkipásztorok kötelességteljesítésük közben semmiben se szenvedjenek hiányt, s előnyben részesüljenek azokkal szemben, akik a nem hivatalos, azaz a római katolikus egyház által jóvá nem hagyott rítusokat alkalmazzák.

2 Iványi Sándor: Az egri püspöki nyomda a 18. században (Vázlat). In: Kétszáz éves az Egri Főegyházmegyei Könyvtár 1793-1993. Emlékkönyv. (Az Egri Főegyházmegye sematizmusa 6.)

Szerk. Antalóczi Lajos. Eger 1993. 255-256.

3 Rituale Agriense i. m. Praefatio 1-3. 
Tekintettel arra, hogy 1761-ben az Egri Egyházmegye területén mintegy 268 pap végzett lelkipásztori munkát, a szertartáskönyv megjelent példányszáma körülbelül 270-300 darab lehetett. ${ }^{4}$

A szóban forgó kötet érdekessége, hogy benne két alkalommal is latin-magyarnémet-,,szláv” nyelvü bejegyzés található egyidejűleg. ${ }^{5}$ A jelen írás ennek a négynyelvüségnek az okát igyekszik feltárni. Arra a kérdésre keresi a választ, milyen módon illeszkedik a könyv kiadása Eszterházy Károly egyházpolitikájába.

\section{Liturgikus könyvek a közép- és az újkori Magyarországon}

A hittérítés jellegéből adódóan a keresztény magyar liturgiában eleinte dél-német, Rajna-menti, észak-itáliai és bizánci hatások érvényesültek. A Szent István király halálát követő évtizedekben a hazai istentiszteleti élet fóleg francia nyelvterületről, Lotaringiából és a Német-római Birodalomból kapott ösztönzést. Ezt a megállapítást három korai liturgikus kódex is alátámasztja: az ún. Szelepcsényi Evangelistarium, amelyet a 11. század végén másolhattak a garamszentbenedeki bencés monostor szerzetesei számára, a szentmisében a pap könyörgéseit tartalmazó Szent Margit Sacramentarium, valamint az 1075-1083 között összeállított Esztergomi Benedictionale, amely frank hagyományokra épülő templomszentelési szöveget őrzött meg. A vízszentelés rítusában salzburgi mintákat követö Hartvik-féle Agenda pontificalis a napkeleti bölcsek betlehemi hódolatát és a „szent asszonyok” Krisztus sírjánál tett látogatását eleveníti fel. A 12. század elejéről származó, s Gyulafehérvárott vagy Székesfehérvárott másolt neumaírásos antifónás könyv, a Codex Albensis már a magyar gregorianizmus bizonyos fokú megnyilvánulását mutatja. A Pray-kódex Nagy Sacramentariuma nyelvtörténeti érdekességgel is szolgál: a Halotti Beszéd és Könyörgéssel, amely népnyelvü prédikációként került a latin nyelvű gyüjteménybe. ${ }^{6}$

4 Sugár István: Az egri püspökök története. (Az Egri Főegyházmegye sematizmusa 1.) Bp. 1984. 430.

5 Rituale Agriense i. m. 14-16. és 20-23. (keresztelés), valamint 86-87., 89-91.és 94-96. (házasságkötés)

6 Radó Polikárp: Hazánk legrégibb liturgikus könyve: a Szelepchényi-kódex. In: Magyar Könyvszemle 63. (1939) 352-412.; Mezey László: A Pray-kódex keletkezése. In: Magyar Könyvszemle 87. (1971) 109-123.; Radó Polikárp: Libri liturgici manuscripti bibliothecarum Hungariae et limitropharum regionum. (Commissio Academiae Scientiarum Hungaricae Pro Historia Libri) Bp. 1973. 230-231.; Török József: A középkori magyarországi liturgia története. In: Kódexek a középkori Magyarországon. Bp. 1985. 52-54.; Török József: A katolikus egyház és liturgia Magyarországon (A kezdetektől a 19. század végéig). (A magyar műveltség 1100 éve) Bp. 2000. 37-38.; Czagány Zsuzsa: Codex Albensis. In: Magyar művelödéstörténeti lexikon. Középkor és kora újkor. II. Főszerk. Köszeghy Péter. Szerk. Tamás Zsuzsanna. Bp. 2004. 61.; Madas Edit. A szóbeliség és az írásbeliség határán 1192-1195: A Halotti Beszéd. In: A magyar irodalom történetei. A kezdetektől 1800-ig. 
A 13-16. században a nyugati eredetű liturgia végleg megszilárdult a Kárpátmedencében, s a szertartások nélkülözhetetlen kellékének számító kéziratos és nyomtatott szerkönyveket úgyszólván minden egyházi intézményben meg lehetett találni. Közülük a legfontosabbak az alábbiak (zárójelben a tartalmuk):

I. A szentmisén használatosak: Sacramentarium (a pap állandó és változó imái), Lectionarium (olvasmányok, szentleckék), Evangeliarium (evangéliumok), Antiphonarius missae vagy Graduale (időszakos énekek, kiegészítve állandó részekkel - Kyrie, Gloria), Missale (teljes misekönyv), Missale notatum (hangjelzésekkel ellátott misekönyv).

II. A zsolozsma végzésekor szükségesek: Psalterium (zsoltárok), Hymnarium (himnuszok), Antiphonale (antifónák, reszponzóriumok), Capitulare (a szertartásvezető imái), Lectionarium officii (olvasmányok), Breviarium (teljes zsolozsma), Breviarium notatum (kottás breviárium).

III. Egyebek: Rituale (a pap és a diakónus által végzett szentségek, szentelmények, körmenetek), Pontificale (püspök-, pap-, templom- és harangszentelés) stb. ${ }^{7}$

A keresztény liturgia a középkorban országonként egyedi jellegzetességeket hordozott, ami fóként a központi szabályozás hiányával magyarázható. A reformáció kibontakozásával azonban a helyzet gyökeresen megváltozott. A Trentói/Trienti Zsinat (1545-1563) után a római pápák a liturgikus könyvek többségét kijavíttatták, $s$ az új változatok bevezetését az egész nyugati egyházban szorgalmazták. ${ }^{8}$

Az első olyan magyarországi rituále, amelynek összeállításakor már figyelembe vették a Trentói Zsinat végzésit, Telegdi Miklós pécsi megyéspüspök és érseki helynök jóvoltából 1583-ban jelent meg Nagyszombatban (Agendarius, liber continens ritus et caeremonias, quibus ... in dioecesi et provincia Strigoniensi utuntur. Quibus additae sunt lingua vernacula piae et catholicae aliquae exhortationes ad eos, qui utuntur sacramentis et qui eorum administrationi intersunt). Ezt követte Pázmány Péter esztergomi érsek 1625. július 26-án kibocsátott szerkönyve (Rituale Strigoniense, seu formula agendorum in administratione sacramentorum ac ceteris Ecclesiae publicis functionibus), amely V. Pál pápa 1614. évi Rituale Romanumához igazodott, de a régebbi magyar szokások egy részét is fenntartotta. ${ }^{9}$ Minthogy a Pázmány-féle

Főszerk. Szegedy-Maszák Mihály. Szerk. Jankovics László és Orlovszky Géza. Bp. 2007. 59-70.; Földváry Miklós István: Az Esztergomi Benedikcionále. Irodalom és liturgia az államalapítás-kori Magyarországon. (Mühelytanulmányok I.) Bp. 2014. 27. és 41.

7 Liturgikus lexikon. Szerk. Kühár Flóris és Radó Polikárp. Komárom 1933. 12., 30., 90., 106107., 232-233., 241., 337., 354. és 359.; Várnagy Antal: Liturgika. Szertartástan. Az egyház nyilvános istentisztelete. Abaliget 1995. 352-361. és 503-505.

8 A középkori és újkori egyetemes liturgiatörténet tanulmányozásához alapvető munka: Radó Polikárp: A megújuló istentisztelet. Múlt - jelen - jövő. Bp. 1973. 53-103.

9 Rajner Lajos: A Rituale-kérdés Magyarországon. Bp. 1901. 58-66.; Mihályfi Ákos: A nyilvános istentisztelet. Bp. 1933.44-45.; Liturgikus Lexikon i. m. 106.; Földváry Miklós István: A Pázmány- 
szertartáskönyv hatálya kiterjedt az egri püspökség területére is, joggal vetődhet fel a kérdés: miért került sor 1768-ban a Rituale Agriense kiadására. A jelenség hátterében meghúzódó tényezők közül legalább három ismérvet kell kiemelni: 1 . a plébániahálózat helyreállításának és a papi fegyelem erősítésének szándékát, amely Eszterházy Károly egyházpolitikájának sarkalatos pontját képezte; 2. a ruszin népesség számának növekedését; 3. a görögkatolikusok egyházkormányzati igényeit, amelyek ellen az egri megyéspüspökök szívós küzdelmet folytattak.

\section{A ruszinok uniós mozgalma az Egri Egyházmegyében}

A 18. századi Magyarországon egyháztörténeti szempontból a legnagyobb horderejü változást az ortodox népesség egy részének Rómával való újra egyesülése idézte elő. A szakirodalomban vallási unióként emlegetett esemény a görögkatolikus (unitus) felekezet megszületését eredményezte, amelynek létszáma a század végére meghaladta a 600000 fót. $^{10}$

Az uniót elfogadó pravoszlávok alapvetően négy kérdésben adták fel korábbi álláspontjukat: elismerték a római pápa egyházföi hatalmát, tudomásul vették a tisztítótűz meglétét, elfogadták a Filioque-tant - azt a katolikus dogmát, miszerint a harmadik isteni személy, a Szentlélek nemcsak az Atyától, hanem a Fiútól is származik -, és hogy a legszentebb Oltáriszentséget kovásztalan kenyérrel is lehet ünnepelni. Mindezekért az engedményekért cserében megtarthatták szertartásaikat és liturgikus nyelvüket, elérték, hogy püspökeiket a papok szinódusa választhatta meg, akiket a pápa erősített meg hivatalukban, papjaiknak pedig, akik elviekben egyenrangúak lettek a római katolikus papsággal, engedélyezték a nősülést és a családalapítást. ${ }^{11}$

A Magyar Királyság területén az uniós mozgalom a ruszin nép körében a 17. század folyamán indult meg. Parthén Péter és Kossovics Gábor erőfeszítéseinek eredményeképpen az ungvári vártemplomban 1646. április 24-én 63 ruszin pap

rituále. http://class-phil.elte.hu/sites/default/files/profilok/foeldvarymiklosistvan/A\%20P\%C3\% A1zm\%C3\%A1 ny-ritu\%C3\%A1le.pdf letöltés 2018. máj. 4.

10 Katus László: Vallások, egyházak (1699-1790). In: Szultán és császár birodalmában. Magyarország művelődéstörténete 1526-1790. (Magyar Kódex 3.) Főszerk. Szentpéteri József. Szerk. Stemler Gyula. Bp. 2000. 323.; Katus László: A modern Magyarország születése. Magyarország története 1711-1914. Pécs 2012. 100.

11 Pirigyi István: A magyarországi görög katolikusok története. I. Bp. 1990. 87.; Pirigyi István: A görögkatolikus magyarság története. Bp. 1991. 27.; Hollós János: A bizánci egyházjog mint a Görög Katolikus Egyház jogforrása Magyarországon a XVII-XVIII. században. In: Posztbizánci Közlemények 1. (1994) 114. 
Jakusich György egri megyéspüspök előtt letette a katolikus hitvallást, s az érintettek egyúttal kijelentették, hogy X. Ince pápát és utódait elismerik legfőbb vezetőjüknek. Példájukat a következő években több egyházi személy is követte Ung, Sáros, Abaúj, Torna, Szepes, Gömör és Felső-Zemplén megyékben. A második szakasz 1664-ben Munkácson kezdődött, s kiterjedt Bereg, Ugocsa, Szatmár, Szabolcs és Zemplén vármegyék déli felére. A harmadik periódus 1721-ben fejeződött be Máramarosban. ${ }^{12}$

VIII. Sándor pápa 1689. november 5-én két brévét adott ki: az egyikben szebasztei püspökké, a másikban a magyarországi ruszin hívek apostoli helynökévé (vicarius apostolicus) nevezte ki a bizánci hagyományokban járatos Joannes De Camillist. A Vatikáni Könyvtár egykori görög származású tisztviselője, miután püspökké szentelték, Bécsbe utazott, ahol I. Lipót német-római császár, magyar és cseh király (16571705) 1690. március 11-én munkácsi püspökké tette meg azzal a feltétellel, hogy utódaival együtt engedelmeskedjék az egri megyéspüspöknek. ${ }^{13}$

Titulusa ellenére az új fôpásztor nem a Szentszéktől függött. Az egri megyéspüspök rítusvikáriusának számított, ezért apostoli helynöki címe nem érintette Fenesy György egyházkormányzati jogkörét. ${ }^{14}$ De Camillis mindenesetre komolyan vette megbízatását, s nagy lendülettel fogott hozzá hivatása gyakorlásához. Missziós munkájának elismeréseként I. Lipót király 1692. augusztus 23-án a ruszin papokat gyermekeikkel együtt kiemelte a jobbágysorból, s a latin rítusú plébánosokkal egyenlő jogokban részesítette őket. ${ }^{15}$ Mivel a rutén lakosság körében a liturgia nyelve

12 Papp György: Az ungvári unió időpontja. Miskolc 1941. 9., 11. és 13.; Pirigyi István: Uniós törekvések az újkori Magyarországon. In: Katolikus egyháztörténeti konferencia Keszthely, 1987. Szerk. Hölvényi György. Bp. 1989. 66.; Pirigyi István: Az ungvári unió. In: Vigilia, 61. (1996) 405-406.; Véghseő Tamás: „....mint igaz egyházi ember...”. A történelmi Munkácsi Egyházmegye görög katolikus egyházának létrejötte és 17. századi fejlödése. (Collectanea Athanasiana. I. Studia. vol. 4.) Nyíregyháza 2011. 55-60.

13 A munkácsi gör. szert. püspökség okmánytára. I. 1458-1715. Gyűjt., összeáll. és közreb.: Hodinka Antal. Ungvár 1911. 289-290. Nr. 236. (1689. november 5.) és 296-297. Nr. 240. (1690. március 11.).; Baán István: De Camillis szebasztei püspökké és apostoli helynökké való kinevezése és felszentelése. In: Rómából Hungáriába. A De Camillis János József munkácsi püspök halálának 300. évfordulóján rendezett konferencia tanulmányai. Nyíregyháza, 2006. szeptember 29-30. Szerk. Véghseő Tamás. (Collectanea Athanasiana. I. Studia. vol. 1.) Nyíregyháza 2008. 141.

14 Szabó Péter: A keleti közösségek katolikus egyházba tagozásának ekkleziológiai elvei és jogi struktúrái az uniók korában (15-17. század). In: Rómából Hungáriába. A De Camillis János József munkácsi püspök halálának 300. évfordulóján rendezett konferencia tanulmányai. Nyíregyháza, 2006. szeptember 29-30. Szerk. Véghseő Tamás. (Collectanea Athanasiana. I. Studia. vol. 1.) Nyíregyháza 2008. 23-33.; Makláry Ákos: Az apostoli vikariátus intézménye a 17. században. In: Rómából Hungáriába. A De Camillis János József munkácsi püspök halálának 300. évfordulóján rendezett konferencia tanulmányai. Nyíregyháza, 2006. szeptember 29-30. Szerk. Véghseő Tamás. (Collectanea Athanasiana. I. Studia. vol. 1.) Nyíregyháza 2008. 156-158.

15 Hodinka A.: Okmánytár i. m. 347-350. Nr. 268.; Pirigyi I.: A magyarországi görög katolikusok i. m. 144.; Véghseő T.: A történelmi Munkácsi i m. 168-170. Nr. 16. 
az egyházi szláv volt, Kollonich Lipót esztergomi érsek a nagyszombati egyetemi nyomdát cirill betűkkel szereltette fel, s ott kinyomtatta a munkácsi fópap számára fontos liturgikus könyveket. ${ }^{16}$

Gróf Eszterházy Károly 1762-től 1799-ben bekövetkezett haláláig állt az egri püspökség élén. Fennhatósága Heves, Borsod, Abaúj, Sáros, Zemplén, Ung, Bereg, Ugocsa, Máramaros, Szatmár és Szabolcs vármegyékre, a Jászságra, a Nagykunságra és a hajdúvárosok egy részére terjedt ki. Ezen a hatalmas területen egri megyéspüspökként, Heves megye örökös főispánjaként, valamint Eger városa és a püspöki birtokok földesuraként tudta érvényesíteni akaratát. ${ }^{17}$

Alighogy megérkezett szolgálati helyére, Eszterházy nyomban összetűzésbe került Olsavszky Emánuel Mihállyal (Olšavský Emanuel/Manuel Michael), akinek - az unitus papság műveltségének és anyagi körülményeinek javításán túlmenően - határozott kívánsága volt egy önálló görögkatolikus egyházmegye felállítása. ${ }^{18}$ Az egyesült papok 1764-ben zsinatra gyültek össze Munkácson, ahol megfogalmazták sérelmeiket, s választott ügyvivőjükön, Bradács Jánoson keresztül arra kérték a királynőt, hogy függetlenítse őket Egertől. ${ }^{19}$

Mária Terézia (1740-1780) 1766. április 30-án levélben indítványozta XIII. Kelemen pápánál a munkácsi püspökség felállítását. Az uralkodónő kezdeményezését a Kúriában két konzisztoriális ügyvéd, Stephanus de Angelis és Aloysius Coquelinus képviselte. ${ }^{20}$ Hogy kellőképpen tájékozódjon az ügyben, az Apostoli Szentszék kikérte Eszterházy véleményét is, aki 1767. március 31-én küldte el terjedelmes - 113

16 Hermann Egyed: A katolikus egyház története Magyarországon 1914-ig. (Dissertationes Hungaricae ex historia Ecclesiae I.) München 1973. 351.; Pirigyi I.: A magyarországi görög katolikusok i. m. 155.

17 Mária Terézia királynő 1761. október 10-én nevezte ki Eszterházy Károlyt egri megyéspüspökké, aki azonban csak 1762. június 29-én kezdte meg fópásztori működését Egerben. Eszterházy életéről korszerủ monográfia mind a mai napig nem készült. A rövidebb összefoglalások közül említésre méltóak az alábbi munkák: Pfeiffer János: Emlékezés gróf Eszterházy Károly püspökről (1725-1799). Veszprém 1940.; Bitskey István: „Püspökünk, példánk és tükörünk volt...” Eszterházy Károly életpályája és egyénisége. In: Eszterházy Károly emlékkönyv. Szerk. Kovács Béla. Eger 1999. 7-22.; Sugár I.: Az egri püspökök i. m. 425-443.

18 Janka György: A katolikus barokk szellemiség a magyarországi görög katolikusoknál. In: Athanasiana 1. (1995) 109-110.; Bosák Nándor: Eszterházy Károly püspök és a görög katolikusok. In: Eszterházy Károly emlékkönyv. Szerk. Kovács Béla. Eger 1999. 167-168.

19 Zsatkovics Kálmán: Az egri befolyás és az ez ellen vívott harcz a munkácsi görög szertartású egyházmegye történelmében. III. In: Századok 18. (1884) 848.; Hodinka Antal: A munkácsi görög-katholikus püspökség története. Bp. 1909. 605-606.; Janka György: Az ezeréves egri egyházmegye és a görög katolikusok. In: Athanasiana 19. (2004) 155.; Joachim Bahlcke: A magyar püspöki kar és a Habsburg Monarchia. Együttműködéstől a konfrontációig (1686-1790). Bp. 2013. 344-345.; Pirigyi I.: A magyarországi görög katolikusok i. m. 158-159.

20 Zsatkovics K.: Az egri befolyás i. m. 851-852.; Hodinka A.: A munkácsi görög-katholikus i. m. 609-613.; Pirigyi I.: A magyarországi görög katolikusok i. m. 162. 
pontba foglalt - beadványát az Örök Városba Opinio et informatio de episcopatu G. R. Munkacsiensis non erigendo címmel. A Tridentinum szellemében nevelkedett föpap elsősorban egyházjogi érvekkel bizonygatta, milyen veszéllyel jár a ruszinok önállósulási törekvése. Írásában hangsúlyozta: Krisztus egyetlen személyt rendelt az egyház kormányzatára, s a részegyházaknak be kell simulniuk a római katolikus egyház hierarchikus rendjébe, amely kizárólag a hatalom osztatlansága és az alattvalók engedelmessége révén valósulhat meg. ${ }^{21}$

XIII. Kelemen pápa hosszas mérlegelés után elfogadta Eszterházy álláspontját, s 1768. július 30-án keltezett levelében kifejtette, hogy az autonóm görögkatolikus egyházmegye felállításához nem járul hozzá. ${ }^{22}$ Mária Terézia tudomásul vette Róma döntését, s 1768. augusztus 24-én elrendelte, hogy a ruszinok fópapja a területileg illetékes egri megyéspüspök joghatósága alá tartozzék. Az uralkodónő egyúttal felszólította Bradács János munkácsi apostoli helynököt, hogy a felmerülő vitás kérdéseket személyesen intézze el Eszterházyval. Ugyanakkor Kaunitz kancellár révén tudatta a pápával, hogy eredeti tervét nem adta fel, hanem csupán felfüggesztette azt. ${ }^{23}$

\section{Következtetések}

Erős a gyanú, hogy a fent vázolt eseménysorozatba illik bele az 1763-ban tervbe vett egri rituále kiadása is, amelynek bevezetője 1766. november 14-én íródott, míg maga a szerkönyv 1768 nyarán-őszén, a nyomda új betűkészletének beszerzése után jelent meg. A magyar, német és „szláv” nyelvű mondatok a keresztelés és a házasságkötés szertartásának ismertetésekor fordulnak elő. Akkor, amikor a jelenlévők élőszóban kapcsolódtak be a szentségek kiszolgáltatásába, illetve, amikor a papnak lehetősége nyílt arra, hogy a híveknek anyanyelvükön hirdesse az egyház tanítását. ${ }^{24}$

21 Janka György: A munkácsi egyházmegye felállítása. In: Athanasiana 4. (1997) 64-70.; Zsatkovics K.: Az egri befolyás i. m. 855-859.; Hodinka A.: A munkácsi görög-katholikus i. m. 614-615.; Bosák N.: Eszterházy Károly püspök i. m. 170-178.

22 Eszterházy Károly 1767. október 5-én az új bécsi nunciust, Giuseppe Garampit is értesítette a ruszinok önállósulási törekvéseiről (A bécsi magyar követség levéltárának iratai Magyarországról 1611-1786. Összegyűjt., vál. és a bev. tan. írta: Vanyó Tihamér Aladár. [Magyarország újabbkori történetének forrásai] Bp. 1986. 164. Nr. 16.).

23 Zsatkovics K.: Az egri befolyás i. m. 859-860.; Hodinka A.: A munkácsi görög-katholikus i. m. 616.; Janka Gy.: A munkácsi egyházmegye i. m. 78.; Bosák N.: Eszterházy Károly püspök i. m. 169.

24 Patachich Gábor kalocsai érsek 1738-ban kiadott rituáléjában szintén a keresztelés és az esketés szertartásának leírásakor találhatók magyar, német és horvát nyelvű részek. Ez utóbbi főleg azoknak a katolikus délszláv népcsoportoknak (sokácok, bunyevácok, rác-horvátok) az érdekeit szolgálta, akiknek nyelvét „Illyrica” néven emlegették a korabeli dokumentumok (Bárth Dániel: 
Eszterházy Károly kitüntetett figyelmet szentelt az Egri Egyházmegye területén élt nagyszámú ruszin lakosság pasztorációjára. Fontosnak tartotta, hogy a római katolikus szertartást minden keresztény hívő a saját nyelvén hallgassa. A katolikus megújulás legcélravezetőbb eszközének a térítést tekintette, s ennek jegyében nyomtatta ki - liturgikus, hitéleti és egyházpolitikai okokból - a szóban forgó munkát. Mária Teréziával folytatott vitájában arra igyekezett rávilágítani, hogy papjai rendelkeznek olyan szertartáskönyvvel, amely képes kielégíteni a magyar, a német és a „szláv” nyelven beszélő közösségek lelki szükségleteit. A német szavakkal tarkított „szláv” nyelvet azok a rus, rusin, rus'kij névvel illetett ortodox és görögkatolikus rutének beszélték, akiknek legnépesebb csoportjait Sáros, Zemplén, Ung, Bereg és Máramaros vármegyékben vették nyilvántartásba az összeírók. ${ }^{25}$

Eszterházy erőfeszítései végül kudarcot vallottak, mivel XIV. Kelemen pápa „Eximia regalium principum” kezdetü bullájával 1771. szeptember 19-én felállította a munkácsi görögkatolikus püspökséget, amelynek metropolitája az esztergomi érsek lett. Az új egyházmegye élére Bradács Jánost nevezte ki a királynő, akit a Szentszék 1771. szeptember 26-án erősített meg hivatalában. ${ }^{26}$ A régmúlt történései iránt érdeklődők számára mindazonáltal nem volt hiábavaló ez a küzdelem, hiszen annak folyamán jelent meg - no és persze maradt fenn - az a rituále, amely ma az egri Főegyházmegyei Könyvtár gyüjteményének féltve őrzött kincse.

Újjáépítés és reform. In: Vigilia 67. [2002] 15.). A történeti hűség kedvéért meg kell említeni, hogy a bűnbánat szentségének tárgyalásakor is előfordulnak magyar nyelvű betoldások az egri szerkönyv szövegében (Rituale Agriense i. m. 64.).

25 Udvari István: Ruszinok a XVIII. században. Történelmi és művelődéstörténeti tanulmányok. (Vasvári Pál Társaság Füzetei 9.) Nyíregyháza 1992. 15. A plébánosok feladatait illetően Eszterházy szintén a Trentói Zsinat előírásait tartotta iránymutatónak. Az áldozópapság kultikus funkciójának lényegét jól megvilágítja Gárdonyi Máté tanulmánya: Gárdonyi Máté: A plébánossal szemben támasztott követelmények a Tridenti Zsinat után. In: Alsópapság, lokális társadalom és népi kultúra a 18-20. századi Magyarországon. Szerk. Bárth Dániel. (ELTE BTK Folklór Tanszék) Bp. 2013. 45.

26 Zsatkovics $K$ : Az egri befolyás i. m. 875-876.; Hodinka A.: A munkácsi görög-katholikus i. m. 624-625.; Pirigyi I.: A magyarországi görög katolikusok i. m. 157-165.; Janka Gy.: A munkácsi egyházmegye i. m. 81.; Joachim B.: A magyar püspöki kar i. m. 349. 


\section{A Ritual Book for the Priests of the Archdiocese of Eger (1768)}

The collection of the Archdiocesan Library of Eger contains many valuable books. One of them is the ritual that was published in print in 1768 , for the priesthood of the Diocese of Eger. Its special feature is that it contains a Latin-HungarianGerman-“Slavic" entry simultaneously. Károly Eszterházy, Bishop of Eger (17621799) considered the release of the publication important for two reasons. First, to provide a handbook for the pastors in his diocese, offering useful guidance for performing priesthood duties outside of Mass. Second, to provide Catholic pastors with an advantage in administering sacraments and sacramentals over those performing rites not accepted by the Roman Catholic Church. Eszterházy placed great emphasis on obstructing the union-aspirations of the Ruthenians in his jurisdiction. The publication of Rituale Ageiense also served this purpose.

\section{Liturgická kniha kňazov jágerského biskupstva (1768)}

Jedným zo skvostov zbierok Arcibiskupskej knižnice v Egeri je Liturgická kniha kňazov jágerského biskupstva. Liturgickú knihu určenú vyslovene farárom tejto cirkevnej provincie nechal v roku 1768 vydat jágerský biskup Karol Eszterházy (1762-1799). Jeho ciel'om bolo ponúknut kňazom vlastnej diecézy manuál vhodný nielen so zretelom na omše ale aj na iné povinnosti. Ďalším jeho cielom bolo, aby farári neboli počas výkonu svojich povinností v ničom ukrátení a aby boli uprednostnení pred tými, ktorí postupujú podla rítov neschválených rímskokatolíckou cirkvou. Zaujímavostou skúmaného zväzku je, že sa vňom nachádzajú aj dva latinskomadarsko-nemecko-"slovanské" záznamy. V štúdii sa pokúsime odhalit aj príčinu vniku týchto viacjazyčných záznamov. Tiež sa zaoberáme s otázkou, do akej miery zodpovedá publikácia cirkevnej politike Karola Eszterházyho. 